\title{
PROVENANCE, TRANSPORT AND COMPOSITION OF DENDÊ COAST BEACH SANDS IN BAHIA, CENTRAL COAST OF BRAZIL
}

\author{
Renata Cardia Rebouças*; José Maria Landim Dominguez and Abílio Carlos da Silva Pinto Bittencourt \\ Universidade Federal da Bahia \\ Instituto de Geociências - Laboratório de Estudos Costeiros/CPGG \\ (Campus Universitário de Ondina, Rua Barão de Geremoabo, s/nº 40170-280, Salvador, BA, Brasil) \\ *Corresponding author: rcr.renata@gmail.com
}

\begin{abstract}
A B S T R A C T
The great physiographic diversity of the Dendê Coast favors the production of different beach sediment types, including bioclastic components. In this study 74 beach samples collected at $2 \mathrm{~km}$ intervals were used to evaluate beach sediment composition. For each sample, 300 grains were identified for each grain size class coarser than $0.125 \mathrm{~mm}$, using a binocular microscope. The beach sediments of the Dendê Coast are essentially siliciclastic (80-100\%). Quartz is the major component (70-100\%). Only at the Tinharé and Boipeba islands bioclasts are major components of beach sands reaching up to $80-100 \%$. These sediments are made up essentially of fragments of Halimeda, reaching percentages up to $70 \%$. Coralline algae and mollusks also contribute significantly to these sediments (up to 30\%). The results obtained show that the spatial distribution of the bioclastic components provide important information on the environmental conditions present at the shoreline (energy levels, availability of hard substrates and protected areas, pattern of sediment dispersion) and on the sediment sources as well. The composition of the beach sediments on the Dendê Coast reflects the present day environmental conditions and show that these sediments do not experience significant lateral transport. This situation is favored by an impeded longshore transport that characterizes most of the region. Although, in general, the rivers that discharge on the Dendê Coast appear to transport few sediments to the coastal zone, the presence of heavy minerals, micas and feldspars suggests river contributions to the beach sediments. On the other hand, the coral and coralline algae reefs, besides offering a natural protection to the shoreline, also represent an important source of beach sands.
\end{abstract}

\section{RESUMO}

A grande diversidade fisiográfica da Costa do Dendê favorece a deposição de diferentes tipos de sedimentos em suas praias, inclusive sedimentos ricos em carbonato de cálcio. Neste estudo 86 amostras de sedimento foram coletadas, em intervalos de $2 \mathrm{~km}$, para avaliação da composição dos sedimentos praiais. Para cada amostra foram identificados 300 grãos por fração granulométrica maior que $0.125 \mathrm{~mm}$, usando uma lupa binocular. Os sedimentos das praias da Costa do Dendê são essencialmente siliciclásticos $(80-100 \%)$. O quartzo é o principal componente (70 - 100\%). Apenas nas ilhas de Tinharé e Boipeba, os bioclastos são os principais componentes alcançando teores entre 80 e $100 \%$. Estes sedimentos são compostos essencialmente de fragmentos de Halimeda, com teores de até $70 \%$. Algas coralinas e moluscos também contribuem significativamente para a composição das areias deste trecho (com teores acima de até $30 \%$ ). Os resultados obtidos mostram que a análise da distribuição espacial dos componentes bioclásticos fornece informações importantes sobre as condições ambientais na linha de costa (níveis de energia, disponibilidade de substratos duros e suprimento de sedimento), assim como sobre as possíveis fontes de sedimento para a praia. A composição dos sedimentos das praias da Costa do Dendê reflete as condições ambientais atuais, e evidenciam que estes sedimentos não experimentam transporte lateral. Essa situação é favorecida pela situação de transporte litorâneo impedido que caracteriza a maior parte da região. Embora, os rios da região pareçam transportar poucos sedimentos para a zona costeira, a presença de minerais pesados, micas e feldspatos sugerem contribuições fluviais para os sedimentos das praias. Por outro lado, os recifes de coral e algas coralinas, além de oferecerem uma proteção natural para a linha de costa, também representam uma importante fonte de sedimentos para as praias.

Descriptors: Sediment composition, Longshore drift, Provenance, Bioclastics, Beach sands, Central coast of Brazil.

Descritores: Composição dos sedimentos, Transporte litorâneo, Proveniência, Bioclastos, Areias de praia, Costa central do Brasil. 


\section{INTRODUCTION}

Exposed sandy beaches may be associated with a variety of coastal habitats (SHORT; HESP, 1999) and thus be inhabited by diverse biological communities (MCARDLE; MCLACHLAN, 1992). As a consequence, in addition to siliciclastic components, the mineralized hard parts of marine organisms, such as mollusks, foraminifera, echinoderms and coralline algae, may integrate the beach sediments (PILKEY; BLACKWELDER, 1968; KING, 1972; MILLIMAN, 1974; KOMAR, 1976). Such a condition occurs especially on tropical beaches, where biological activity is intense, as well as on beaches where the continental sediment supply is reduced (KOMAR, 1976). Usually the carbonate grains are produced in the submerged zone of the beach and subsequently transported by the action of waves and currents towards the beach face (WILSON, 1975). In this respect, McLachlan et al. (1993) suggest that wave action is one of the major factors governing the distribution of macrofauna within the beach sands.

The coastal stretch of the State of Bahia located between the rivers Jequiriçá and Tijuípe (Fig. 1), known as the Dendê Coast, presents a very irregular coastline, due to the presence of islands, bays and tidal channels. Along its oceanic coastline, with overall characteristics of impeded longshore drift, there are several segments of sandy beach associated with different ecological conditions. The objective of this paper is to characterize the composition of these beach sediments, with emphasis on bioclastic constituents, as well as to analyze the spatial variations thereof, as a function of source areas and associated ecosystems, wave energy and coastal sediment drift.

\section{Geological and Physiographic Scenario}

The coastal region under study (Fig. 1) is bounded internally, in its greater part, by hills of Mesozoic rocks (sandstones and carbonates) with average heights of approximately 40 meters. In the southern portion of the area, it is bounded by Precambrian basement, in the form of steep cliffs, with average heights of approximately 170 meters. In the region between the mouths of the Contas and the Tijuípe Rivers, the Precambrian basement borders the coastline in the form of rocky coasts (DOMINGUEZ, 2006).

The coastal plain is occupied, in its major part, by marine Pleistocene and Holocene sandy terraces, and locally, by clay-organic mangrove and wetland deposits, and sandy deposits, of fluvial origin
(Fig.1) (MARTIN et al., 1980). Coral and coralline algae reefs, fringing and adjacent to the beach, occur in significant stretches along the coastline (Fig. 1) (LEÃO et al., 2003).

In the present paper, the Dendê Coast's oceanic coastline is divided into four sectors, in the light of its physiographic characteristics, described below, beginning in the North (Fig. 1):

Sector I - Encompasses a beach arc, between the Jequiriçá River and Ponta do Curral, $20 \mathrm{~km}$ in length, predominantly composed of fine sands (FREITAS, 2002) and bordered by a Holocene marine terrace.

Sector II - Encompasses the islands of Tinharé and Boipeba, characterized by a barrier of fringing coral and coralline algae reefs (with small shallow back-reef lagoons) along the major part of the coastline (LEÃO et al., 2003). The beaches in this sector are intercalated by small segments of active sea cliffs sculptured in Mesozoic rocks, which propitiates the existence of several pocket beaches. These beach cliffs vary in height between 5 and 80 meters and may present sandy beaches at their base. The texture of the beach sediments ranges from fine to coarse sands. In some sections, the coastline is characterized by the presence of mangroves. This is a sector with a great variety of ecosystems.

Sector III - Encompasses a beach arc, $18 \mathrm{~km}$ in length, between Carvalhos Bar and Ponta do Apaga Fogo, composed of fine to medium sands and bordered by a Holocene marine terrace. Ebb-tidal deltas characterize the extremities of this sector.

Sector IV - Encompasses the coastal sections between Ponta do Mutá and the Tijuípe River, presenting fine to medium sand beaches. From Ponta do Mutá to Contas River, the beaches are continuous, locally presenting small and sparse coral and coralline algae banks adjacent to the beach, without back-reef lagoons. The beaches are bordered by a Holocene marine terrace. From the Contas River to the Tijuípe River, the rocky coast with crystalline basement outcrops, propitiate, in the northern half of the section, the existence of pocket beaches. In the southern half of the sector the beaches are continuous. The Quaternary deposits in this sector show incipient development.

Regarding the direction of net longshore transport along the Dendê Coast, the geometry of sandy terraces, at least in the northern half of the study area, suggests a north to south direction (Fig. 1), which was confirmed by numerical modeling, as discussed below. Also Bittencourt et al. (2005), based on numerical modeling of wave refraction diagrams, described a net longshore drift from south to north for the coastal segment between the Tijuípe River and Ponta do Mutá (Fig. 1). 


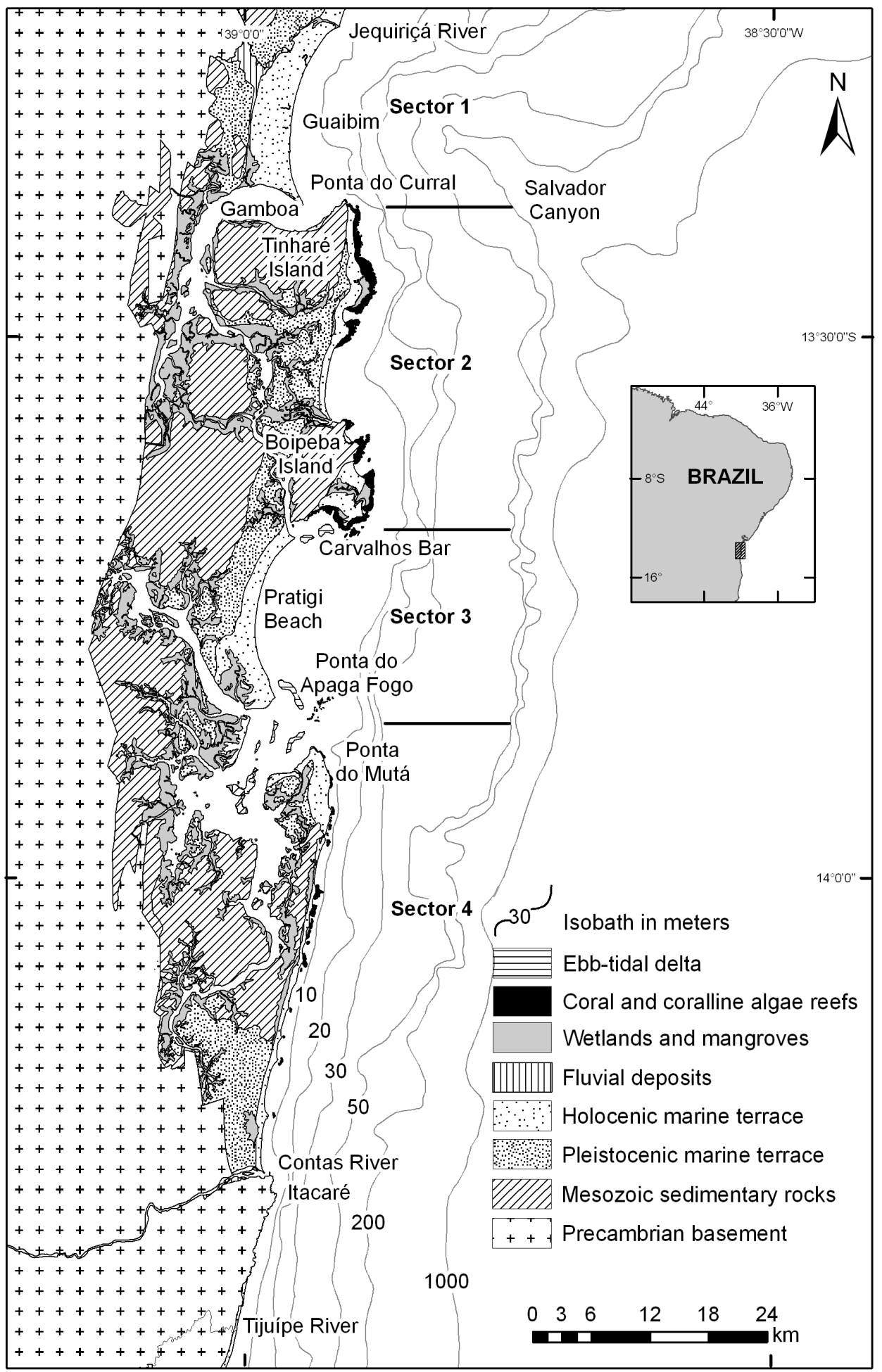

Fig. 1. Geological map of the Dendê Coast and neighboring regions. Also shown are the major physiographic features of the continental shelf. 
The continental shelf presents a maximum width of $26 \mathrm{~km}$ in front of the Pratigi beach, and a minimum of $6 \mathrm{~km}$ in front of the Contas River (Fig. 1) (DOMINGUEZ, 2006; FRANÇA, 1979; FREIRE; DOMINGUEZ, 2006). The major feature in the area is the Salvador canyon, which reaches the internal shelf. The bathymetric contours are also noteworthy due to their irregularity, in the region in front of the coastal section between the Pratigi beach and Gamboa. The shelf break occurs at a depth of approximately 40-50 meters (Fig. 1). In general the superficial layer of the continental shelf is composed of sandy siliciclastic sediments to the $10 \mathrm{~m}$ isobath (DOMINGUEZ, 2006; FREIRE; DOMINGUEZ, 2006; KOWSMAN; COSTA, 1979). Exceptions to this occur in the proximities of the Jequiriçá River (L.M.B. Freitas, personal communication) and Carvalhos Bar (R.K.P. Kikuchi, personal communication), where there are submerged coral and coralline algae reefs (Fig. 1). From the $10 \mathrm{~m}$ isobath to the edge of the shelf, carbonatic sands and gravelly sediments of biogenic origin occur, as well as localized muddy material (KOWSMAN; COSTA, 1979; DOMINGUEZ, 2006; FREIRE; DOMINGUEZ, 2006).

As for the rivers that discharge their waters on the Dendê Coast, the potentially most significant in terms of sediment supply are the Contas and Jequiriçá, with average discharge rates of $143.3 \mathrm{~m} 3 / \mathrm{s}$ (SEIA, 2009) and $15.9 \mathrm{~m} 3 / \mathrm{s}$ (GENZ et al., 2003), respectively.

Tides are semidiurnal with an average amplitude of 2.5 meters, with the spring tides averaging 2.8 meters (Data from the city of Salvador, located approximately $60 \mathrm{~km}$ northeast of Jequiriçá River) (Fig. 1).

\section{Materials AND Methods}

Wave Regime and Sediment Longshore Transport

Direct measurements for the wave regime in the study area are not available. However, the predominant waves are classified as of the sea type (DAVIES, 1972), which is confirmed by the wave statistics exhibited in Hogben and Lumb (1967). The average directions and annual frequencies of local winds which can generate waves affecting the coastline are the following: $\mathrm{NE}\left(\mathrm{N} 45^{\circ}\right)-18 \%, \mathrm{E}(\mathrm{N}$ $\left.90^{\circ}\right)-47 \%$, SE (N 135 $)-30 \%$, SSE (N 157.5 ) - 5\%. These data correspond to a temporal series from 1951 to 1972 (DHN, 1993), registered in Salvador.

The wave conditions used in the present paper were extracted from Hogben and Lumb (1967), who registered data by visual observations on the open sea, taken from ships, which naturally imply uncertainties and inaccuracies. These data are organized in angular sectors which, for the purpose of the present study, were grouped into four sets, as shown in Figure 2. These wave conditions were attributed to the wind frequencies from the same directions described above.

Based on these data, a numerical wave modeling was undertaken using Mike 21 NSW software, developed by DHI Water and Environment. Based on bathymetry taken from a nautical chart of the Brazilian Navy, on the approximate scale of $1: 300,000$, an interpolation was made by the IDW method extending to the $3 \mathrm{~m}$ isobath. The wave transformation modeling was conducted without accounting for factors such as bottom friction, diffraction, interaction with currents and winds, and the influence of tides, which naturally affect the accuracy of the model. The analysis is, therefore, restricted exclusively to the wave refraction phenomenon.

Based on the refraction diagrams, the directions of net longshore drift of sediments were determined by the calculation of the potential intensity of longshore drift for each of the different wave-front directions, in accordance with the method described in Bittencourt et al. (2005). Thus, the potential longshore drift intensity for each wave-front was expressed as a non-dimensional number, in accordance with the function:

$\mathrm{X}=\operatorname{sen} \alpha \cdot \cos \alpha \cdot \mathrm{H}^{2}$

where $\mathrm{X}$ is the longshore drift intensity, $\alpha$ is the incidence of the angle of the orthogonal to the wavefront to the coastline, and $\mathrm{H}$ is the normalized wave height (i.e., the results were divided by a constant with the value of $1 \mathrm{~m}$ ).

The coastline was divided into 25 segments, each of which approximated to a straight line, in accordance with the lie of the coastline. In figure $3 \mathrm{~A}$, the direction and dimension of the arrows correspond to the straight-line segments. Next, starting with the refraction diagrams, the average values of wave heights and the angle of the incidence of each segment were computed. In the majority of the coastal segments corresponding to the islands of Tinhare and Boipeba, for reasons imposed by the scale of observation used in the present paper, the straightlining of the coastline segments smoothed their irregularities, thus locally modifying the angles of incidence of the wave fronts with them.

The modeling in the vicinity of the ebb-tide deltas was not undertaken, since it was not possible to evaluate their influence on wave refraction, since they were not adequately represented on the nautical chart. 


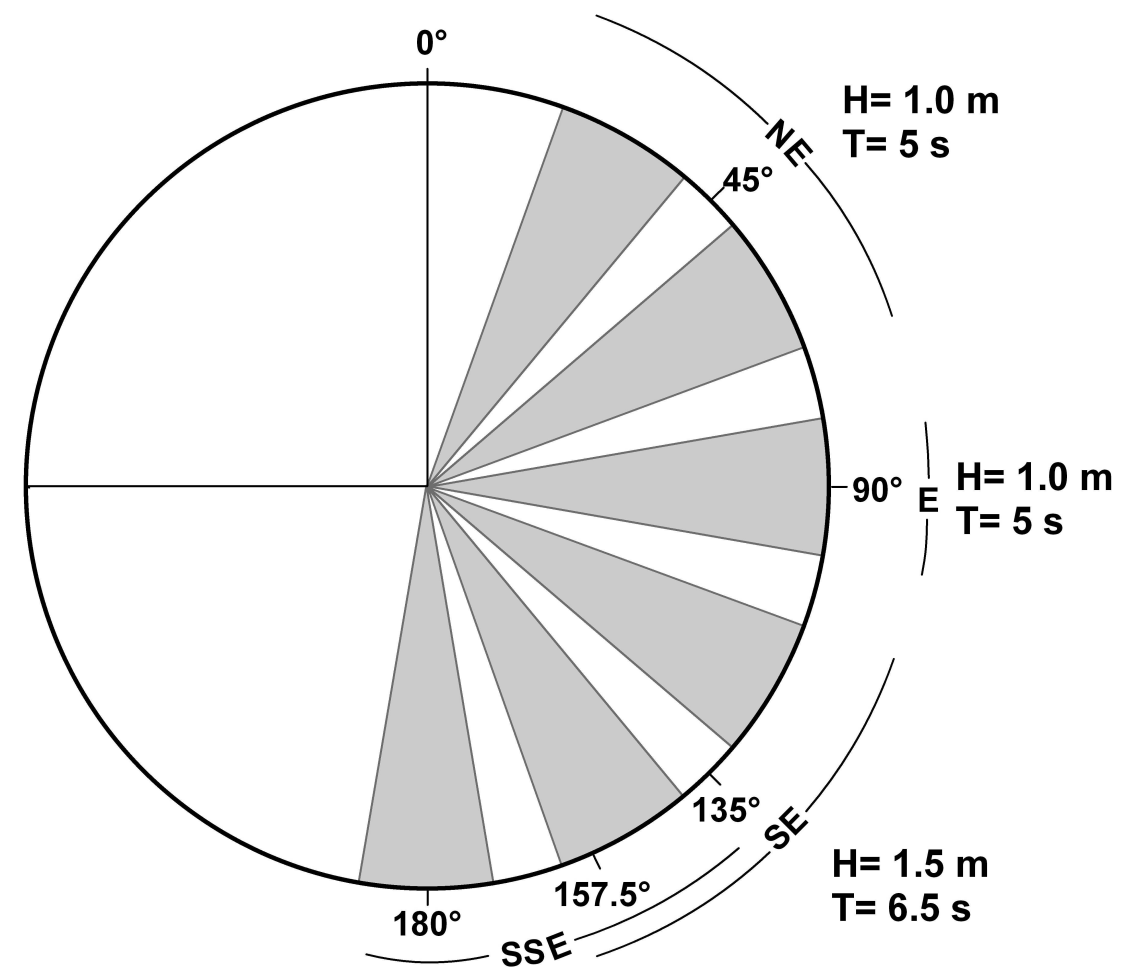

$\mathrm{H}=1.5 \mathrm{~m}$

$\mathrm{T}=6.5 \mathrm{~s}$

Fig. 2. Representative scheme of the manner in which wave data are discriminated (bold areas) in Hogben and Lumb (1967) in the directions considered in the present paper. The average azimuths and predominant periods and corresponding heights are identified.

\section{Sediment Composition}

The value obtained for drift intensity was multiplied by the percentage of annual frequency of the direction of the wind associated with the wavefront under consideration. In the coastal segments that present opposite drift directions throughout the year, the direction of the net drift was defined considering the predominant direction, given by the difference of intensity between the opposing drifts.

Seventy-four sediment samples were collected at $2 \mathrm{~km}$ intervals, representative of the upper $2 \mathrm{~cm}$ of the beach face (Fig. 3C). The sample was dry sieved at of $1 \Phi$ (phi) interval. Compositional analyses were carried out only on those grain size fractions above fine $(0.125 \mathrm{~mm})$. The frequency of each constituent was determined through observation of
300 grains from each fraction, with a binocular microscope. The frequency of the different sediment grains in a sample was determined taking into account the weight of each grain size fraction following a procedure described in Ginsburg (1956) and Purdy (1963).

The bioclasts were identified using a diagnostic key published in Milliman (1974). Some organisms such as the mollusks were grouped in just one class. The genus Halimeda was separated from the articulated calcareous algae group, due to its importance as a component of the beach sediments in the region. Components present in insignificant numbers, such as bryozoans, worm tubes, echinoderms, articulated calcareous algae, foraminifera, sponge spicules and non-identified grains were grouped under the generic term of "others". 


\section{Results}

Wave Regime and Sediment Longshore Transport

Figure 3A shows the net longshore drift directions modeled for the different segments into which the coastline was divided, as well as those extracted from geomorphic indicators, it becoming evident that they are compatible with each other. One exception to this is to be observed in the vicinity of Ponta do Curral, which may be related to diffraction processes probably induced by the northern extremity of the Tinharé Island, a fact not taken into consideration in the modeling. It is important to note that there are divergencies in the direction of net longshore drift at the islands of Tinhare and Boipeba and near the Contas River.

Figure 3B shows the average wave height along the coastline, at $1 \mathrm{~km}$ intervals. This figure shows that the greatest wave heights (between 0.6 and $1.1 \mathrm{~m}$ ) were found in the upper half of Sector I, in some segments corresponding to coral reefs and coralline algae reefs of Sector II, and in all of Sector IV. The smallest wave heights (between 0.1 and $0.2 \mathrm{~m}$ ) were found in Sector III. In the case of Sectors II and IV, it should be remembered that, where a barrier of coral and coralline algae reefs exists, there is a tendency to a considerable reduction in the height of the waves that reach the beach (KENCH; BRANDER, 2006), thus making them significantly smaller than those foreseen in the numerical model. However, it is reasonable to expect that this reduction should be greater in Sector II, due to the presence of back-reef lagoons.

\section{Sediment Composition}

Figure 3C shows the results of the composition analysis. It is possible to identify, with relation to the four sectors into which the coastline was divided, two types of sedimentary grains (siliciclastic and bioclastic), and different concentrations and associations of bioclastic components, as described below:

Sector I: Composed essentially of siliciclastic sands (83 to $100 \%$ of total sample). Regarding the bioclasts, the greater percentages were found in the northern portion of the sector, with a preponderance of coralline algae and mollusks. Heavy minerals were found throughout the entire beach, attaining a maximum of $6 \%$. Micas and feldspars, with a maximum of $1 \%$, are present in the northern half of the sector.

Sector II: Composed essentially of bioclastic sands ( 80 to $100 \%$ of total sample), with a marked preponderance of Halimeda, followed by coralline algae and mollusks. On the Barra Beach (Fig. 3A) there is a significant predominance of siliciclasts (up to $96 \%$ ). Heavy minerals are practically inexistent.

Sector III: Composed essentially of siliciclastic sands (70 to $98 \%$ of total sample). Regarding the bioclasts, crustaceans and mollusks predominate. Heavy minerals occur practically along the entire beach, with a maximum contribution of $2 \%$.

Sector IV: Composed essentially of siliciclastic sands (92 to $100 \%$ of total sample). The bioclasts are composed of coralline algae and mollusks, which are absent from the vicinity of the Contas River. Heavy minerals are found throughout all the beaches, with concentrations up to $12 \%$. Micas and feldspars occur nearly exclusively in the southern half of the sector, reaching concentrations of up to $9 \%$.

\section{Discussion ANd Conclusion}

The sediment composition of the Dendê Coast beaches directly reflects the levels of energy, sources and patterns of sediment dispersion and the existence of protected areas and hard substrates.

The distribution of bioclasts shows a significant correlation with dominant environmental conditions in each sector of the coastline. Where coral reef and coralline algae barriers exist, with protected shallow low energy lagoons to their rear (Sector II, Fig. 3A), Halimeda grains are the most abundant constituent of beach sands (Fig. 3C). Furthermore, these circumstances also favor the existence of a large variety and quantity of bioclastic components in the beach sediments (Fig. 3C). It is also important to note that only on the beaches of Sectors II and III are crustacean fragments present among the bioclastic components (Fig. 3C), which can be attributed to the prevailing low wave heights (Fig. 3B) already described. In fact, these organisms, according to Milliman (1974) and Short and Hesp (1999), due to the fragility of their exoskeletons, can only be preserved in low energy environments.

In the coastal segments where coral reef and coralline algae reef banks are present adjacent to the beach (without back-reef lagoons, Sector IV, Fig. 3A), the small variety and abundance of bioclastic components (Fig. 3C) may be attributed to the prevailing greater wave energy levels than those of Sector II. Furthermore, the reduced abundance of biodetritus in this coastal segment may also be related to the longshore drift (Fig. 3A) which distributes the riverborne sediments delivered by the Contas River and thus contributes to the dilution of the bioclastic components (Fig. 3A). 

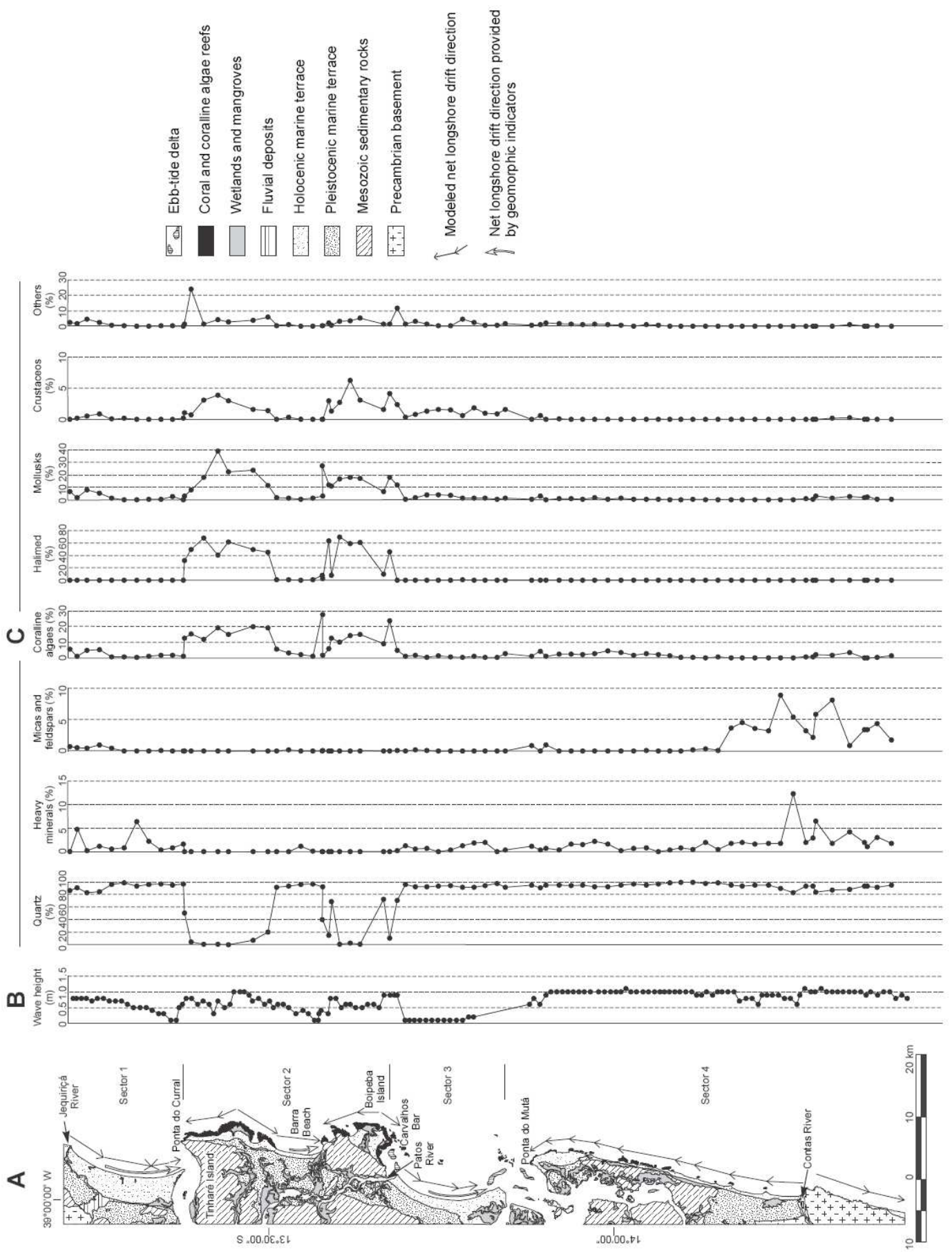

Fig. 3. (A) Geological map and net longshore sediment transport; (B) average wave height along the coastline; (C) composition of beach sediments.

On the other hand, the absence of protected environments behind the reef banks in Sector IV does not favor the growth of Halimeda algae, as is the case in Sector II. Regarding the coralline algae clasts that appear in the beach sediment of a small coastal segment below the Contas River (Fig. 3C), these may have their origin in the coralline-algae crusts present in the rocky coasts to be found there (Fig. 1) (R.K.P. 
Kikuchi, personal communication). Further, regarding Sector IV, there is a considerable coastal segment, from the Contas River toward the North, where no bioclastic components occur in the beach sediments (Fig. 3C). This absence appears to be related to dilution by riverborne sediments and to the absence of hard substrates, thus inhibiting the development of coralline algae and other organisms.

Regarding the coralline algae biodetritus on the beaches of Sectors I, II (Barra Beach) and III (Fig. $3 \mathrm{~A})$, their origin may be related: a) in Sector I, to the submerged coralline-algae reef in the vicinity of the Jequiriçá River, b) on Barra Beach, to the corallinealgae reef which limits the beach at its Northern extremity, and c) in Sector III, to the coralline-algae reef existing in the vicinity of Carvalhos Bar. Finally, it should also be remembered that the location of the coral-algae reefs in Sector II may have been favored by the existence of two divergence zones in the net longshore drift existing in the Sector (Fig 3A). In fact, it is probable that such divergence zones favored the exposure of the existing Mezosoic rocks, which were then used by corals and coralline algae as substrates (BITTENCOURT et al., 2008).

Regarding the origin of the siliciclastic components, Almeida (2004), after modeling the sediment production of the Jequiriçá River (Sector I) (Fig. 3A), concluded that the river could not be the only source of the sediments for the progradation of the adjacent coastal plain to the south. She suggested that the $4 \mathrm{~m}$ drop in sea level that affected the study area during the Holocene (MARTIN et al., 1980, 2003) was responsible for supplying part of the sediments for the progradation of the coastline. This argument has been used by other authors (MARTIN et al., 1980, 1987; DOMINGUEZ, et al. 1987, 1992) to explain the progradation of the coastline of the Brazilian East-Northeast region. However, even if in general the rivers that discharge their waters onto the Dendê Coast seem to contribute little sediment to the coastal zone, the presence of heavy minerals, distributed along the beaches located downdrift of the rivers Jequiriçá (Sector I) and Contas, Sector IV (Figs. $3 \mathrm{~A}$ and $3 \mathrm{C}$ ), as well as the presence of micas and feldspars (Sectors I and IV) (Fig. 3C), suggest a fluvial contribution to the sediments of these beaches. In addition to quartz, these rivers transport other minerals present in the crystalline basement and in the sedimentary rocks that outcrop in their hydrographic basins. The Contas River basin is the most important source of allochthonous sediments to the study area, not only because of its dimensions (55 $334 \mathrm{~km} 2)$, but also because it has a highly dissected relief, characterized by an extensive eluvial-colluvial cover, in addition to the fact that it flows during the entire year, differently from the other rivers that discharge onto the Dendê Coast (CEPLAB, 1979). In the vicinity of the Contas river's mouths, the beach sands show higher percentages of micas, feldspars and heavy minerals (Fig. 3C). These sandy riverborne sediments are then distributed laterally by the longshore drift (Fig. 3A). On the other hand, the dominance of siliciclastic components in front of the crystalline basement outcrops (Figs. 3A and 3C) points to the local contribution of these rocks.

Finally, the results of the present paper show that on the Dendê Coast, the composition and distribution of bioclastic components in the beach sediment directly reflect wave energy levels, and the availability of hard substrates and protected areas. This fact shows that, although the classical papers on sediment provenance emphasize the siliciclastic fraction (COLONY, 1932; BEAL; SHEPARD, 1956; GILES; PILKEY, 1965; POTTER, 1986, 1994), the analysis of the distribution of the bioclastic components can also propitiate means to adequately infer the environmental conditions along the coastline.

\section{ACKNOWLEDGMENTS}

R. C. Rebouças is grateful to CAPES (Coordenação de Aperfeiçoamento de Pessoal de Nível Superior - Coordination for Professional Training of University Level Personnel) for her Master's degree scholarship, J. M. L. Dominguez and A. C. S. P. Bittencourt are grateful to CNPq (Conselho Nacional de Desenvolvimento Científico e Tecnológico - National Council for Scientific and Technological Development) for their Research Productivity Grant.

\section{REFERENCES}

ALMEIDA, A. B. Modelagem da produção de sedimentos na bacia hidrográfica do Rio Jequiriçá - implicações na zona costeira. 2004. 58p. Monografia (Graduação), Instituto de Geociêcias, UFBA, Salvador, 2004.

BEAL, M. A.; SHEPARD, F. P. A use of roundness to determine depositional environments. J. Sediment. Petrol., v. 26, p. 49-50, 1956.

BITTENCOURT, A. C. S. P.; DOMINGUEZ, J. M. L.; MARTIN, L.; SILVA, I. R. Longshore transport on the northeastern Brazilian coast and implications to the location of large scale accumulative and erosive zones: an overview. Mar. Geol., v. 219, p. 219-234, 2005.

BITTENCOURT, A. C. S. P.; LEÃO, Z. M. A. N.; KIKUCHI, R. K. P.; DOMINGUEZ, J. M. L. Deficit of sand in a sediment transport model favors coral reef development in Brazil. An. Acad. Bras. Cienc., v. 80, p.205-214, 2008.

CEPLAB (Centro de Planejamento da Bahia). Bacias hidrográficas do Estado da Bahia. Bahia: Publicações Ceplab, 1979. 109 p. (Série Recursos Hídricos).

COLONY, R. J. Source of the sands on the south shore of Long Island and the coast of New Jersey. J. sediment. Petrol., v.2, p.150-159, 1932. 
DAVIES, J. L. Geographical variation in coastal development. New York: Longman Group, 1972. 204 p. (Geomorphology Text Series no. 4).

DHN (Diretoria de Hidrografia e Navegação) Atlas de Cartas Piloto - Oceano Atlântico, de Trinidad ao Rio da Prata. Brasilia, DF.: Brazil Navy, 1993. 13 p.

DOMINGUEZ, J. M. L. Projeto Costa do Dendê. Salvador: Companhia Baiana de Pesquisa Mineral/ Universidade Federal da Bahia, 2006. 131 p.

DOMINGUEZ, J. M. L., MARTIN, L.; BITTENCOURT, A. C. S. P. Sea level history and the quaternary evolution of river mouth-associated-beach-ridge plains along the eastsoutheast coast of Brazil: a summary. In: NUMMEDAL, D.; PILKEY, D.H.; HOWARD, J. D. (Ed.). Sea level fluctuation and coastal evolution. SEPM Spec. Publ., v.41, p. 208-215, 1987.

DOMINGUEZ, J. M. L., BITTENCOURT, A. C. S. P.; MARTIN, L. Controls on quaternary coastal evolution of the East-Northeastern coast of Brazil: roles of sea level history, trade winds and climate. Sediment. Geol., v. 80, p.213-232, 1992

FRANÇA, A. M. C. Geomorfologia da margem continenta leste brasileira e da bacia oceânica adjacente. In: HERNANI, C. (Ed.). Geomorfologia da margem continental brasileira e das áreas oceânicas adjacentes. Rio de Janeiro: Petrobrás, 1979. (Série REMAC, v.7, p. 89-127).

FREIRE, A. F. M.; DOMINGUEZ, J. M. L. A sequência holocênica da plataforma continental central do Estado da Bahia. Bolm Geociênc. Petrobrás, v. 14, 247-267, 2006

GENZ, F., LESSA, G. C., CIRANO, M. AND LIMA, G. M. P. As tendências de longo prazo das vazões fluviais no litoral do Estado da Bahia. In: CONGRESS OF ABEQUA (Associação Brasileira de Estudos do Quaternário), 9.,Recife. Anais..., 2003, p. 25-29.

GILES, R. T. E.; PILKEY, O. H. Atlantic beach and dune sediments of the Southern United States. J. sediment. Petrol., v. 35, p.900 - 910, 1965.

GINSBURG, R.N. Environmental relationship of grain size and constituent particles in some South Florida carbonate sediments. Am. Ass. Petrol. Geol. Bull., v. 40, p.23812427, 1956.g

HOGBEN, N.; LUMB, F. E. Ocean Wave Statistics London: National Physical Lab., Ministry of Technology, 1967. 263 p.

KENCH, P. S. AND BRANDER, R. W. Wave process in coral reef flats: implication for the reef geomorphology using Australian case studies. J. coast. Res., v. 22, p.209-223, 2006

KING, C.A.M. Beach and coasts. London: Edward Arnold, $1972.570 \mathrm{p}$

KOMAR, P. D. Beach processes and sedimentation Englewood Cliffs, N.J.: Prentice-Hall , 1976. 544 p.

KOWSMAN, R. O.; COSTA, M. A. Sedimentação quaternária da margem continental brasileira e das áreas oceânicas adjacentes. Rio de Janeiro: Petrobrás,1979. (Série REMAC, v. 8, 55 p.).

LEÃO, Z.M.A.N.; KIKUCHI, R.K.P.; TESTA, V. Corals and coral reefs of Brazil. In: CORTÉS, J. (Ed.). Latin America coral reefs. Berlin: Elsevier Science, p. 9-52. 2003.
MARTIN, L.; BITTENCOURT, A. C. S. P.; VILAS BOAS, G. S.; FLEXOR, J. M. Mapa geológico do Quaternário costeiro do Estado da Bahia - 1:250 000 Texto Explicativo. Bahia: Secretaria das Minas e Energia/Coordenação Produção Mineral, 1980. 57 p.

MARTIN, L., SUGUIO, K., FLEXOR, AND J. M., BITTENCOURT, A. C. S. P. Quaternary evolution of the central part of the Brazilian coast: the role of relative sea level variation and shoreline drift. UNESCO Repts mar. Sci., v. 43, p.97-115, 1987.

MARTIN, L.; DOMINGUEZ, J. M. L.; BITTENCOURT, A. C. S. P. Fluctuating Holocene sea levels in east and Southeastern Brazil: evidence for multiple fossil and geomorphic indicators. J. coast. Res., v. 19, p.101-124, 2003.

MCARDLE, S. B. AND MCLACHLAN, A. Sand beach ecology: swash features relevant to the macrofauna. J. coast. Res., v. 8, p.398-407, 1992.

MCLACHLAN, A., JARAMILLO, E., DON, T. E., AND WESSELS, F. Sandy beach macrofauna communities and their control of the physical environment: a geographical comparison. J. coast. Res., v. 15, Spec. Issue, p. 27-38, 1993.

MILLIMAN, J. D. Marine carbonates. New York: Springer, 1974. 375 p.

PILKEY, O.H. AND BLACKWELDER, B. W. Mineralogy of the sand size carbonate fraction of some marine terrigenous and carbonate sediments. J. Sediment. Petrol. v.38, p. 799-810, 1968.

POTTER, P.E. South American and a few grains of sand: Part 1 - Beach Sands. J. Geol., v. 94, p. 301-319, 1986.

POTTER, P.E. Modern sands of South America: composition, provenance and global significance. Geol. Rundsch., v. 83, p.212-232, 1994.

PURDY, E.G. Recent calcium carbonate facies of the Great Bahama Bank. 2. Sedimentary facies. J. Geol., v. 71, p.472-497, 1963.

SEIA (Sistema Estadual de Informações da Bahia) Data base available at: < http://www.cra.ba.gov.br>. Accessed on 13/April/ 2009.

SHORT, A.D. AND HESP, P.A. Beach Ecology. In: SHORT, A.D. (Ed.). Handbook of Beach and Shoreline Morphodynamics. London: John Wiley \& Sons, p.271278, 1999.

WILSON, J. M. Carbonate facies in Geologic History. New York: Springer, 1975. 471 p.

(Manuscript received 17 September 2010; revised 26 May 2011; accepted 08 June 2011) 